\title{
The impact of the Madden-Julian Oscillation on hydrological extremes
}

$$
\text { Jian Peng }{ }^{1,2,3,4} \text {, Simon Dadson }{ }^{1}, \text { Guoyong Leng }^{5 *} \text {, Zheng Duan }{ }^{6} \text {, }
$$

1 School of Geography and the Environment, University of Oxford, OX1 3QY Oxford, UK;

2 Institute for Climate and Global Change Research, School of Atmospheric Sciences, Nanjing University, 210023 Nanjing, China;

3 Department of Geography, University of Munich (LMU), 80333 Munich, Germany;

4 Max Planck Institute for Meteorology, 20146 Hamburg, Germany;

5 Environmental Change Institute, University of Oxford, OX1 3QY Oxford, UK;

6 Chair of Hydrology and River Basin Management, Technical University of Munich, Munich 80333, Germany;

7 Microwaves and Radar Institute, German Aerospace Center (DLR), 82234 Wessling, Germany;

* Authors to whom correspondence should be addressed: E-Mail: guowd@nju.edu.cn (Weidong Guo), guoyong.leng@ouce.ox.ac.uk (Guoyong Leng), jian.peng@ouce.ox.ac.uk (Jian Peng). 


\section{Abstract}

Extreme climate events such as severe droughts and floods have become more frequent and widespread in the 21st Century. Recent studies have revealed the tele-connections between Madden-Julian oscillation (MJO) and extreme precipitation over different regions such as South America, India and China. This study investigates the influence of MJO on global extreme dry and wet conditions, and how the strength of the relationship changes across the MJO phases over the globe. The Evaporative Stress Index (ESI) calculated from global GLEAM evapotranspiration dataset is used to represent extreme dry and wet conditions. Strong correlations between MJO and extreme dry and wet conditions are found, particularly over monsoon regions such as South Asia, South America and East Africa. The underlying mechanism of the influence of MJO on extreme dry and wet conditions is associated with the variation of precipitation, air temperature and soil moisture modulated by the MJO. The study suggests that MJO impacts on extreme dry and wet conditions should be taken into account in investigation of droughts/floods around the world particularly over monsoon areas.

Keywords: Madden-Julian oscillation, GLEAM, evaporative stress index, CCI soil moisture, GPCP precipitation, ERA-Interim

\section{Introduction}

Climate extremes such as floods and droughts have significant impacts on natural system, human, society and economy in vulnerable regions (Easterling et al. 2000; Meehl et al. 2000; Zhang et al. 2019). The Fifth Assessment Report of the Intergovernmental Panel on Climate Change (IPCC) has indicated that the frequency, intensity, and duration of some climate extreme events will increase by the end of this century (IPCC 2013). However, there are large 
discrepancies on climate extreme events projections in Coupled Model Intercomparison Project phase 5 (CMPI5) and the older CMIP3 collections (Knutti and Sedláček 2013; Sillmann et al. 2013). Therefore, understanding, modeling and predicting climate extremes has been identified as one of the World Climate Research Programme (WCRP) Grand Challenges (Sillmann et al. 2017). Various processes determine the onset, duration and recovery of climate extremes particularly floods and droughts at multiple temporal (seasonal, annual, and decadal) and spatial scales (local, regional, continental) (Dai 2013; Frei et al. 2006; Sun et al. 2016a). In general, climate extremes are strongly influenced by modes of climate variability such as El NiñoSouthern Oscillation (ENSO), the North Atlantic Oscillation (NAO) and the Pacific Decadal Oscillation (PDO) (Kenyon and Hegerl 2010; Weisheimer et al. 2017; Zhang et al. 2010). In recent years, the ENSO, NAO, and PDO have been widely studied and identified as the source of climate predictability for global dry/wet conditions seasonal forecasting (Barlow et al. 2001; Cayan et al. 1998). The current climate models are also able to simulate the gross characteristics of these modes of climate variability (Sillmann et al. 2017). However, it is still challenging in sub-seasonal climate extremes forecasting because of the poor ability of models to simulate Madden-Julian Oscillation (MJO) (Inness and Slingo 2003; Robertson et al. 2018; Waliser et al. 2003). A recent report from Robertson et al. (2018) emphasized the importance of the MJO in sub-seasonal forecasts over the tropics and remarkable progress of the representation of MJO in the operational models. However, they also highlighted that the impacts of MJO on weather through teleconnections are still not well captured by the models, which limits the sub-seasonal to seasonal predictability of extreme weather and climate. Therefore, the projections of regional climate extremes over South Asia, West Asia, Southeast Asia and Australia are highly uncertain when associated with MJO. 
The MJO is a tropical intra-seasonal oscillation that is characterized by a large scale convection system propagating from the Indian Ocean to the Pacific Ocean with a speed of 5-10 $\mathrm{ms}^{-1}$ (Madden and Julian 1971; Zhang 2005). Typically, the MJO shows an intraseasonal variability with time scale of 30-90 days, which is characterized by enhanced convection across the western Indian Ocean and suppressed convection over the western Pacific Ocean. It has been found that the MJO can modify the extratropical circulation by acting as diabatic heating source (Matthews et al. 2004). It plays an import role in the global weather-climate system and influences many weather and climate phenomena. Previous studies have found that the MJO has effects on precipitation (Jones et al. 2004a), surface temperature (Zhou et al. 2016), snow cover (Li et al. 2016), tropical cyclones (Frank and Roundy 2006), tornadoes (Thompson and Roundy 2013), fire (Reid et al. 2012), soil moisture (Peng et al. 2017a), EI Niño Southern Oscillation (Pohl and Matthews 2007), Wyrtki jets (Han 2005) and several other weather and climate events (Zhang 2013). Several studies have found a strong relationship between MJO and extreme precipitation over specific regions such as South America, India and China (Joseph et al. 2009; Lü et al. 2012; Shimizu et al. 2017). Although floods are caused by complex interactions between atmosphere, ocean and land (Seager et al. 2013; Sheffield et al. 2009; Sun et al. 2016a; Sun et al. 2016c), these studies revealed the impacts of ocean states on the occurrence of extreme precipitation. In addition, several studies reported the impacts of MJO on droughts in China and India (Joseph et al. 2009; Lü et al. 2012; Neena et al. 2011). All these previous studies have concentrated on the impacts of MJO on either extreme precipitation or droughts over specific geographic locations. However, the impacts of MJO on droughts and floods at global scale are rarely explored. As MJO has been considered as a major source of intra-seasonal climate predictability in many dynamical forecasting systems (Kang and Kim 2010; Liu et al. 2017b; 
Sun et al. 2014; Tan et al. 2017; Waliser et al. 2003) and the planetary scale of MJO, a better understanding of the influence of MJO on global extreme dry and wet conditions is essential for improving the forecasting of sub-seasonal extreme precipitation and droughts. With the ability to accurately identify, model and forecast the MJO, it will provide valuable information for operational climate risk management.

The aim of the present study is to investigate the spatial distribution of the land extreme dry and wet conditions and its spatial and temporal variation connected to the MJO phases. To our knowledge, this study is the first time to provide a global of view of the slow eastward propagation of the MJO and the occurrence of extreme dry and wet conditions over the globe. The study is mainly based on satellite products, and uses Evaporative Stress Index (ESI) (Anderson et al. 2007) to represent global extreme dry and wet conditions. It should also be noted that the definition of drought is much more complex than flooding. A wide range of drought indexes has been developed to identify drought over the last decades (Zhang and He 2016; Zhang et al. 2015). The ESI represents the standardized anomaly of the evapotranspiration (ET) fraction (actual ET/potential ET) and has been widely used for monitoring drought and wetness conditions (Anderson et al. 2015; Choi et al. 2013; Otkin et al. 2014). The MJO has been found to have significant influence on precipitation, air temperature and soil moisture (Zhang 2013), which also to some extent represent the status of dry and wet conditions. Thus, the statistical relationship between these climate variable and ESI are also quantified during MJO events to reveal the mechanism of influence of the MJO on global extreme dry and wet conditions. The following section introduces the details about data and methodology used for the analysis. Section 3 presents and discusses the results. The conclusions drawn from this study are summarized in Section 4. 


\section{Data and Methodology}

\subsection{Data}

Both reanalysis and satellite datasets are used in this study. These datasets mainly include Global Precipitation Climatology Project (GPCP) daily precipitation (Huffman et al. 2001), Global Land Evaporation Amsterdam Model (GLEAM) daily evapotranspiration/potential evapotranspiration (ET/PET) (Martens et al. 2017; Miralles et al. 2011), European Space Agency's Climate Change Initiative (ESA CCI) soil moisture (Dorigo et al. 2015b; Liu et al. 2011) as well as wind speed and air temperature from ERA-Interim reanalysis datasets (Dee et al. 2011). These datasets are briefly introduced below.

GPCP precipitation: the GPCP global precipitation dataset was produced based on rain gauge, satellite and sounding data with the support of World Climate Research Program (WCRP) and GEWEX activities (Huffman et al. 2001). The GPCP provides globally complete precipitation dataset at $1^{\circ}$ spatial resolution and daily time scale from October 1996 to present. The dataset has been widely validated and applied in various studies (e.g., Hu et al. 2007; Sylla et al. 2013; Trenberth et al. 2018).

GLEAM evapotranspiration: the GLEAM aims to estimate evapotranspiration from satellite observations (Martens et al. 2017; Miralles et al. 2011). The actual evapotranspiration components are based on Priestley and Taylor's (Priestley and Taylor 1972) potential evapotranspiration equation constrained by a multiplicative stress factor. GLEAM provides both actual evapotranspiration and potential evapotranspiration at daily temporal resolution and $0.25^{\circ}$ spatial resolution from 1980 to 2017 . The GLEAM evapotranspiration datasets have been widely validated against global FLUXNET measurements and applied for many hydro-meteorological applications such as global land wetting and drying trend analysis, regional climate response to 
greening of Earth, El Niño-La Niña cycle and recent trends in continental evaporation, and drought monitoring (Forzieri et al. 2017; Greve et al. 2014; Lian et al. 2018; Martens et al. 2017; Miralles et al. 2014; Richard et al. 2018; Vicente-Serrano et al. 2018).

ESA CCI soil moisture: the CCI soil moisture product was generated by fusion of existing active and passive satellite-based soil moisture datasets within the framework of the ESA Climate Change Initiative (Liu et al. 2011). It provides global soil moisture estimate at daily time scale and at a spatial resolution of $0.25^{\circ}$ from 1978 to 2016. Since the first release of the dataset in 2012, there are a wide range of validation and applications been conducted at either regional scale or global scale (e.g., Dorigo et al. 2015a; Miralles et al. 2014; Peng and Loew 2017; Peng et al. 2017d; Peng et al. 2016). Particularly, it has been applied widely for drought monitoring and assessment (Liu et al. 2017a; Nicolai-Shaw et al. 2017; Yuan et al. 2015).

ERA-Interim reanalysis wind speed and air temperature: the ERA-Interim is a global atmospheric reanalysis product that is generated with ECMWF 4-dimensional variational analysis (4D-Var) data assimilation system. The ERA-Interim covers the period from 1979 to present and provides 6 -hourly data at a spatial sampling of about $0.7^{\circ}$. The ERA-Interim datasets such as wind speed, air temperature and soil moisture have been widely evaluated and applied in various studies (e.g., Betts et al. 2009; Peng et al. 2015; Szczypta et al. 2011).

The GPCP precipitation and ERA-Interim wind speed were applied to calculate the real-time multivariate MJO (RMM) as described below. The GLEAM ET/PET were used to calculate evaporative stress index for representing dry/wet conditions. The ESA CCI soil moisture and ERA-Interim air temperature were applied to investigate the underlying mechanisms of MJO's effects on extreme dry and wet conditions. To make all these datasets consistent, all of them 
were reprocessed to $0.25^{\circ} \times 0.25^{\circ}$ grid size using bilinear interpolation method and to daily time scale for a 17-year period (January 1997 to December 2013).

2.2 MJO index and composite analysis

The MJO is normally identified and tracked with an MJO index. One of the commonly used MJO indices is the real-time multivariate MJO (RMM) index (Wheeler and Hendon 2004), which is constructed based on empirical orthogonal functions (EOF) analysis of combined fields of outgoing long-wave radiation (OLR) or precipitation and $850-\mathrm{hPa}$ and $200-\mathrm{hPa}$ zonal wind anomalies (Crueger et al. 2013; Waliser et al. 2009). The first two normalized principal components are usually referred as RMM1 and RMM2, which are in quadrature and represent a propagating mode. The MJO eight phase life cycle is then defined depending on the sign and amplitude of RMM1 and RMM2. The MJO event is identified when the RMM index amplitude is larger than 1 :

$$
R M M=\sqrt{R M M 1^{2}+R M M 2^{2}}
$$

The MJO events are then separated into eight phases, corresponding to the location and strength of the MJO convection from the Indian to the Central Pacific oceans (Wheeler and Hendon 2004). In this study, the GPCP precipitation and ERA-Interim zonal winds at 850-hPa and 200hPa were used to calculate RMM index and identify MJO events. In addition, the MJO has strong seasonal variability with a primary convective signal appearing in the Northern Hemisphere during boreal summer, and a convection anomaly centered in the Southern Hemisphere during boreal winter (Kim et al. 2017; Zhang and Dong 2004; Zhou et al. 2012). Therefore, the composite analysis in this study was examined based on two seasons: boreal summer (May-October) and boreal winter (November-April). 
2.3 Evaporative stress index and statistical analysis

The Evaporative Stress Index (ESI) (Anderson et al. 2007) was used in this study to exhibit global dry/wet conditions. The ESI represents the standardized anomaly of the evapotranspiration (ET) fraction (actual ET/potential ET) (Anderson et al. 2016). It is considered to be uniquely sensitive to changes in soil moisture and vegetation water content due to the association of ET with temperature, precipitation, radiation, and wind (Leng et al. 2017; Otkin et al. 2013). Therefore, the ESI has been widely used for monitoring drought and wetness conditions (Anderson et al. 2015; Choi et al. 2013; Otkin et al. 2014). The ESI is calculated as the standardized anomaly of ET fraction (Otkin et al. 2014):

$$
\operatorname{ESI}(t, x, y)=\frac{v(t, x, y)-\frac{1}{n} \sum_{1}^{n} v(t, x, y)}{\sigma(x, y)}
$$

where $\mathrm{v}$ refers to ET fraction, $\mathrm{v}(\mathrm{t}, \mathrm{x}, \mathrm{y})$ denotes the ET fraction at day $\mathrm{t}, \mathrm{n}$ is the number of days, $\mathrm{x}, \mathrm{y}$ is grid location, and $\sigma(x, y)$ is the standard deviation. Negative ESI values show the dry conditions, indicating vegetation that is stressed because of insufficient soil moisture. The recently released GLEAM v3.2 global ET and potential ET datasets provides a unique opportunity to calculate global spatial resolution ESI, which was used in the current study.

The spatial pattern correlation analysis was used to investigate the relation between dry/wet conditions and precipitation, soil moisture and air temperature. The statistical significance of the correlation analysis and composite analysis was tested using the Student's ttest with confidence level of $95 \%$. 


\section{Results and discussion}

\subsection{Analysis of global dry/wet conditions over different phases of MJO}

The composite analysis of the impacts of MJO on extreme dry and wet conditions was explored during MJO days. Figure 1 shows the composite maps of the ESI over eight MJO phases for summer and winter respectively. It should be noted that only areas with $\mathrm{P}$ value less than 0.05 are shown, indicating the results are statistically significant at $95 \%$ level. In general, the figure shows that the MJO has impacts on the variation of dry and wet patterns in many parts of the world particularly over monsoon regions such as South Asia, southern Brazil, North American, Australia, as well as East Africa. The presence of dry and wet conditions and their variations across MJO phases over these areas agree well with the variations of monsoon systems (Zhang 2013). For example in boreal summer, the dryness was observed in South Asia in MJO phase 1, while wetness was shown in MJO phase 2, 3 and 4. From phase 6 to 8 , the dryness was observed again. The intraseasonal variations of dryness and wetness correspond well with the variations of summer monsoon over India caused by MJO (Joseph et al. 2009; Pai et al. 2011). In addition, the dryness and wetness of non-monsoon regions such as East Africa is also affected by MJO. The wetness is shown in phase 3 and 4 while dryness is found in phase 6 and 7 during boreal winter, which is likely related to the corresponding heavy rain and light rain. What is the mechanism through which MJO can influence dry and wet conditions? Previous studies have found that the MJO plays an import role in modulating precipitation (e.g., Jones et al. 2004b), surface air temperature (e.g., Vecchi and Bond 2004) and soil moisture (e.g., Peng et al. 2017a). The impacts of MJO on these variables are related to modifying the meridional overturning circulations (He et al. 2011), and exciting Rossby wave trains caused by heating anomaly (Zheng et al. 2018), and moisture transport (Jia et al. 2011), and forcing zonally-propagating equatorial 
Rossby and Kelvin waves (Janicot et al. 2009). Through these teleconnections, the MJO modulate the precipitation, surface air temperature and soil moisture over the globe (Donald et al. 2006; Matsueda and Takaya 2015; Peng et al. 2017a). For example, the MJO can influence the extreme precipitation in USA through a phenomenon known as "atmospheric river" transporting moisture from the tropical central Pacific to the west coast of the USA (Dettinger 2011). The impacts of MJO on dry and wet conditions found in the current study might be related to the abovementioned teleconnection mechanism. One explanation for dry condition induced by MJO relates to the deficiency of rainfall. In addition, the air temperature above normal further increases the soil moisture evaporation. For MJO effects on wet conditions can be explained by tropical-extratropical teleconnections, through which the MJO influences extreme rainfall and air temperature and further lead to extreme wet conditions. For example, the ESI signal shown in Figure 1 is consistent with precipitation patterns found by previous studies (Donald et al. 2006; Zhang 2013). In particular, the onset of the South Asian monsoon is found to occur more likely (50\%-80\%) in MJO phases 2 and 3, which will induce a spike in rainfall over South Asia during boreal summer (Zhang 2013). Another example is east Africa, where Pohl and Camberlin (2006) found $72 \%$ of extreme rainfall occurs near coastal regions when the MJO center is over the Indian Ocean (phase 2) during boreal winter. These MJO induced extreme precipitation events can also been observed in figure 1, where extreme wet conditions expressed by ESI anomaly occur over South Asia in MJO phase 2 and 3 during boreal summer, and east Africa in phase 2 during boreal winter. To test the above assumption that the dry and wet condition is due to the combined impacts of MJO on precipitation, air temperature and soil moisture, a correlation analysis between dryness/wetness and precipitation, soil moisture and air temperature is conducted in the next section. 

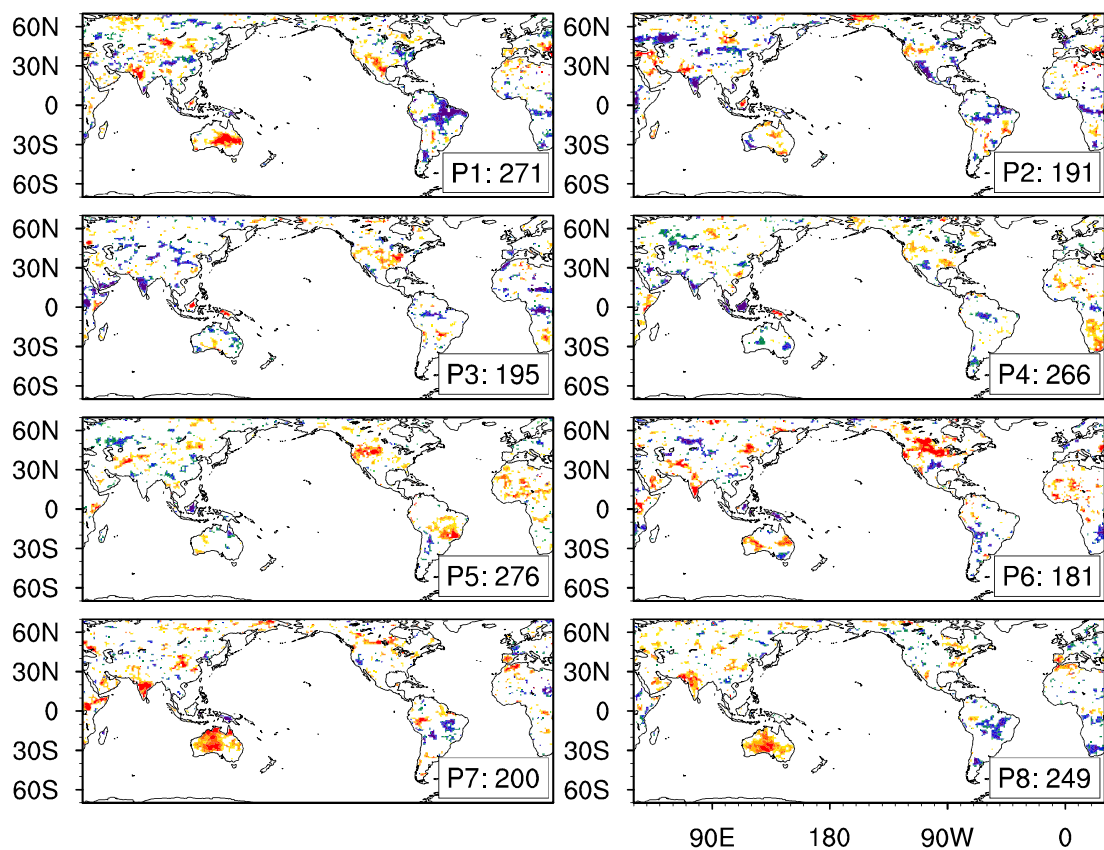

(a)

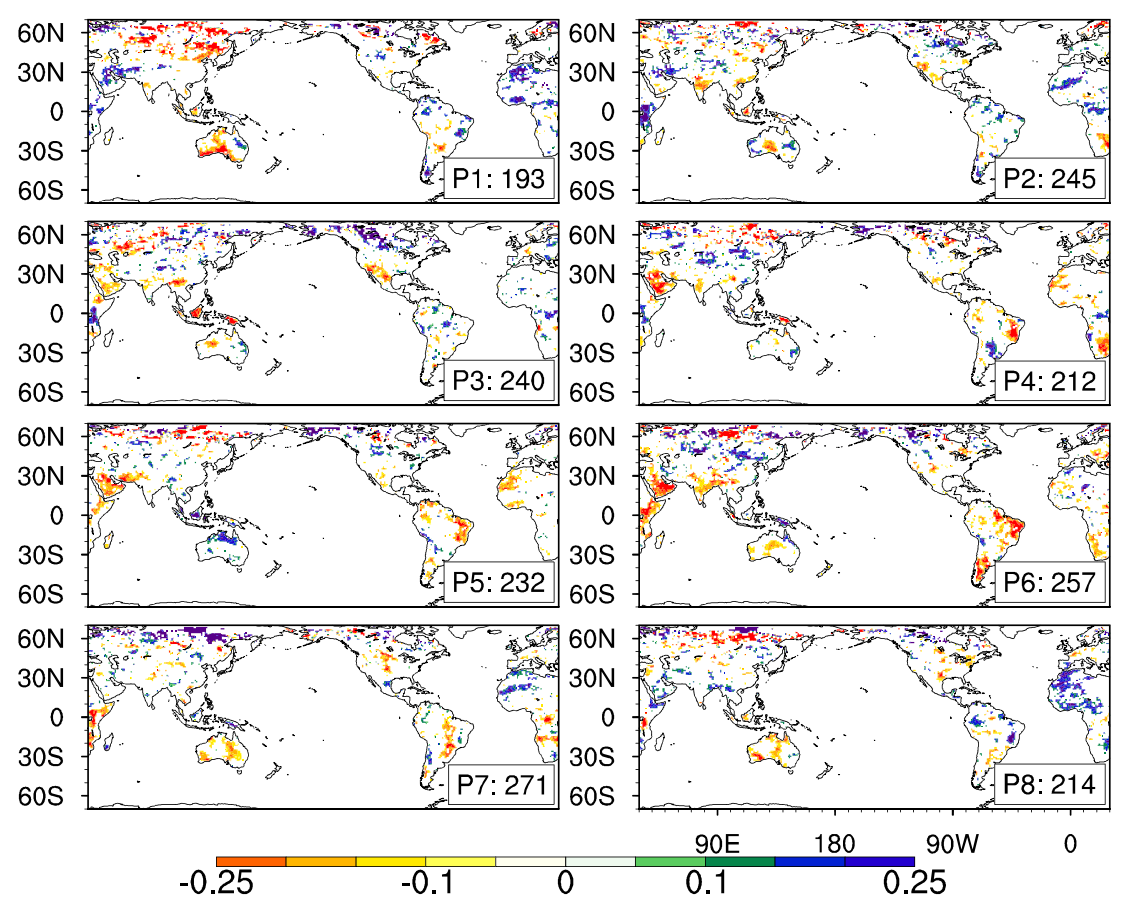

(b)

Figure 1: Composites of Evaporative Stress Index anomalies over eight MJO phases for boreal summer (a) and boreal winter (b). The P together with a number represents the MJO phase and the corresponding number of days. It should be noted that only the areas with statistically significant results $(p<0.05)$ are shown. The ESI values larger than 0 refers to wet conditions while the values less than 0 implies dry conditions. 
3.2 Correlation analysis between dry/wet conditions and rainfall, soil moisture and air temperature

The correlation coefficient between dry/wet patterns represented by ESI and precipitation, soil moisture and air temperature over the globe and across MJO phases are shown in Figure 2, 3 and 4 , respectively. The grey areas refer to masked areas with $p>0.05$. In general, the dryness and wetness over the globe during MJO events are related to precipitation, soil moisture and air temperature. The positive correlation is found between dryness/wetness and precipitation, as well as soil moisture, while air temperature has negative correlation with dry/wet patterns. It is likely due to that dry conditions favor more solar radiation and less evaporative cooling, which is consistent with published studies such as (Trenberth and Shea 2005). The relative high correlation was observed in monsoon areas such as South Asia, Australia, and South America where MJO has strong effects. In addition, the correlation also varies with seasons and variables. For example, the high correlation only appears in boreal summer for South Asia, which corresponds well to the monsoon season in South Asia (Xavier et al. 2014). And significant correlation with precipitation and soil moisture but not with air temperature was found in Australia, which suggests that precipitation, soil moisture and air temperature contribute unequally to the dryness/wetness caused by MJO.

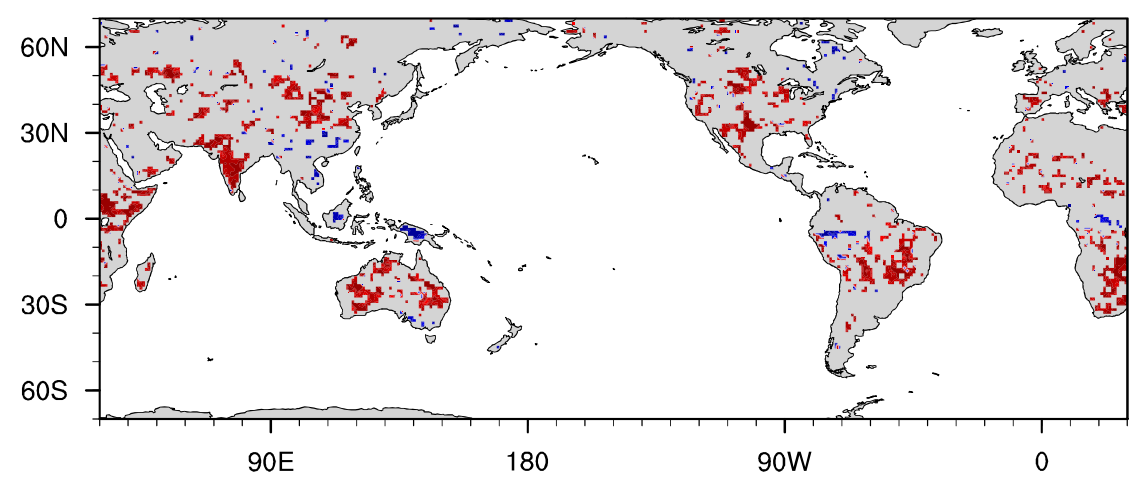

(a) 
Figure 2: The correlation coefficient (R) between Evaporative Stress Index and GPCP precipitation anomaly composites across the MJO phases at each grid point: (a) boreal summer and (b) boreal winter. Only areas with statistically significant results $(\mathrm{p}<0.05)$ are shown.

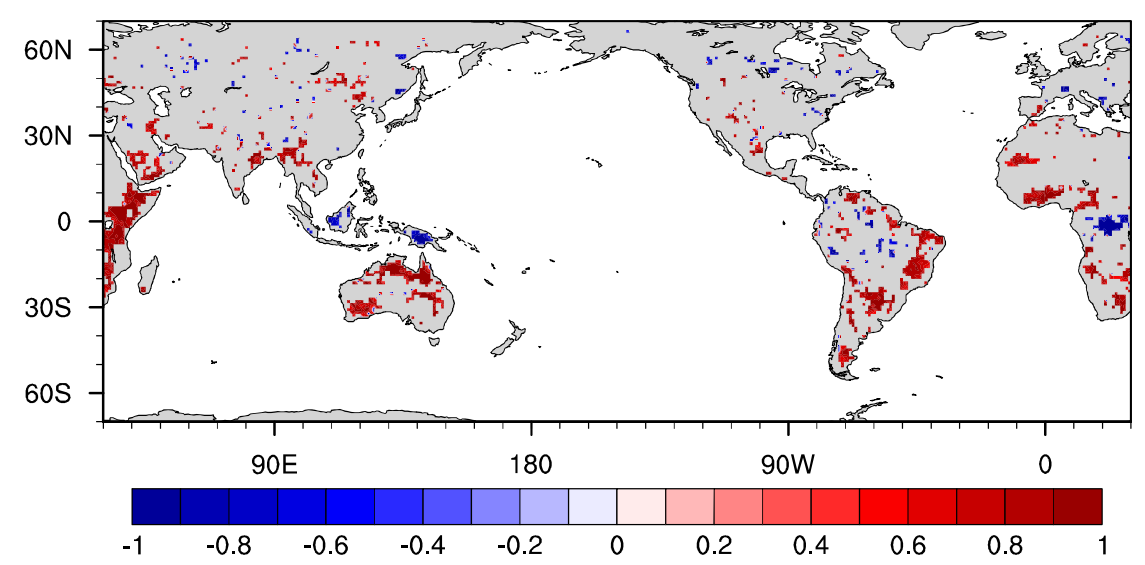

(b)

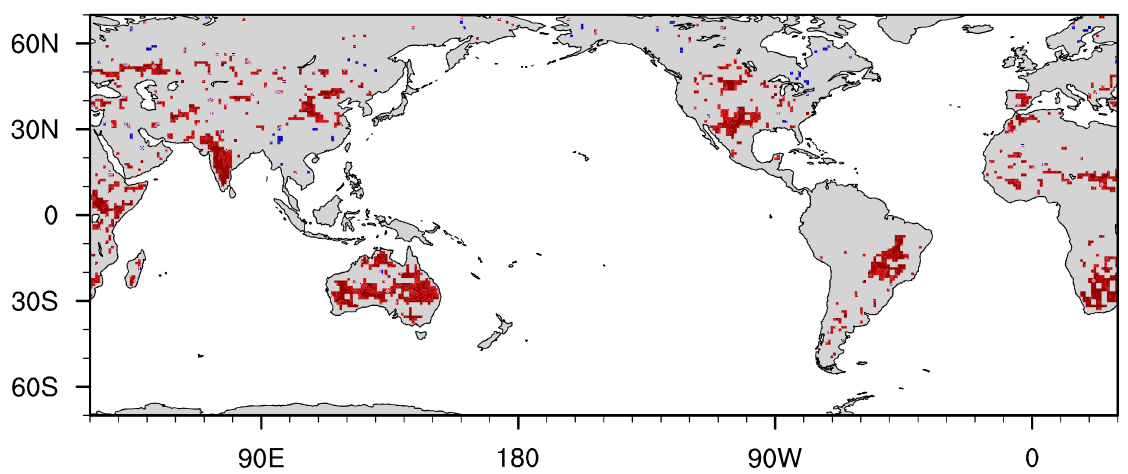

(a)

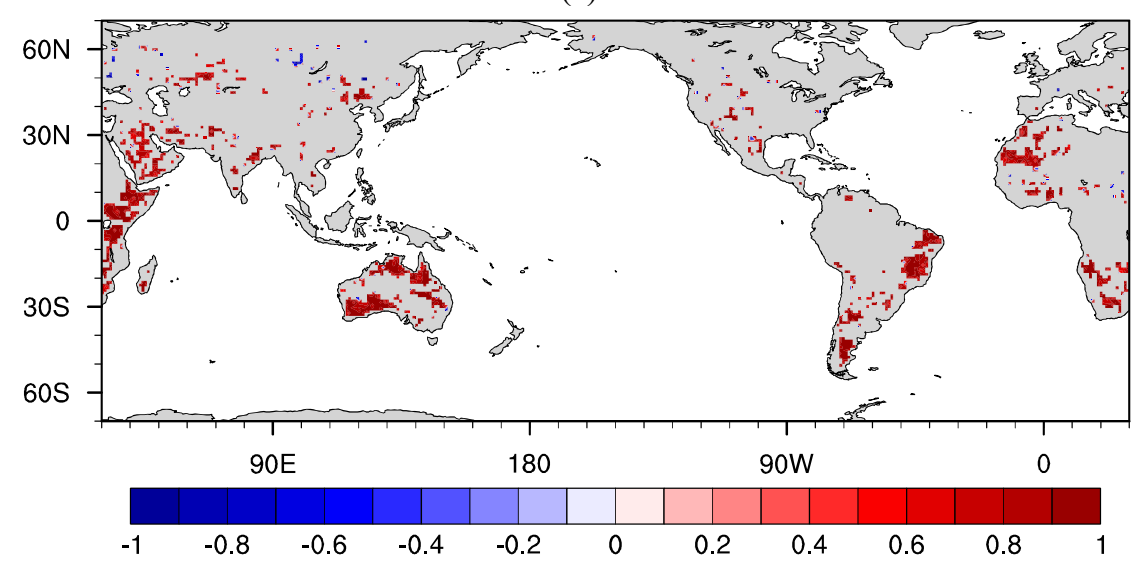

(b) 
Figure 3: The correlation coefficient $(\mathrm{R})$ between Evaporative Stress Index and ESA CCI soil moisture anomaly composites across the MJO phases at each grid point: (a) boreal summer and (b) boreal winter. Only areas with statistically significant results $(\mathrm{p}<0.05)$ are shown.

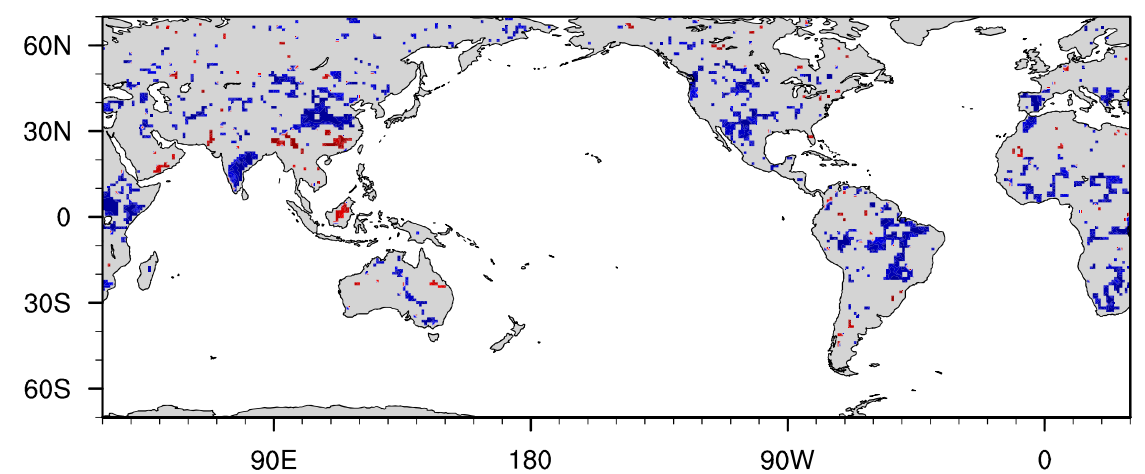

(a)

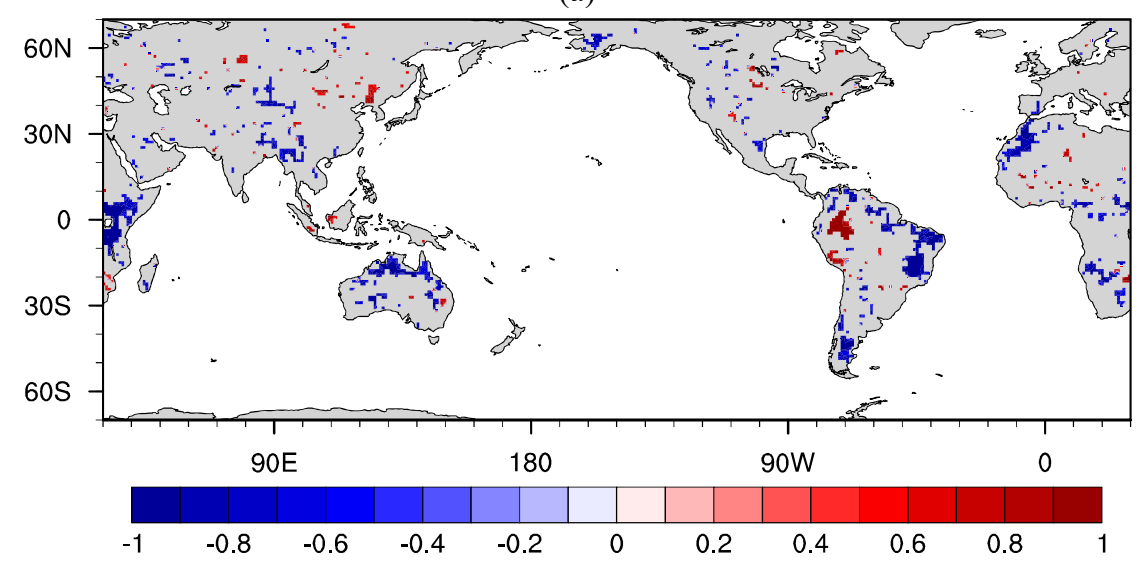

(b)

Figure 4: The correlation coefficient (R) between Evaporative Stress Index and ERA Interim air temperature anomaly composites across the MJO phases at each grid point: (a) boreal summer and (b) boreal winter. Only areas with statistically significant results $(\mathrm{p}<0.05)$ are shown.

Furthermore, the average correlation coefficient values between dry/wet conditions and precipitation, soil moisture and air temperature over the whole globe and regions with strong MJO impacts are shown in Table 1 . These selected regions are South Asia $\left(5^{\circ} \mathrm{N}-27^{\circ} \mathrm{N}, 70^{\circ} \mathrm{E}-\right.$ $\left.90^{\circ} \mathrm{E}\right)$, east part of South America $\left(5^{\circ} \mathrm{S}-40^{\circ} \mathrm{S}, 35^{\circ} \mathrm{W}-60^{\circ} \mathrm{W}\right)$, Australia $\left(11^{\circ} \mathrm{S}-45^{\circ} \mathrm{S}, 110^{\circ} \mathrm{E}-\right.$ $\left.155^{\circ} \mathrm{E}\right)$, and East Africa $\left(10^{\circ} \mathrm{N}-30^{\circ} \mathrm{S}, 32^{\circ} \mathrm{E}-56^{\circ} \mathrm{E}\right)$. Compared to the $\mathrm{R}$ values over the entire globe, the $\mathrm{R}$ values are increased over these sub-regions, further indicating that the strong MJO 
impacts on these areas. The $\mathrm{R}$ values between dryness/wetness and soil moisture are higher than 0.699 for all these regions and slightly better than that for precipitation and air temperature, which agrees well with the characteristics of ESI. Overall, the results presented here suggest that the MJO has impacts on intraseasonal variations of both soil moisture and precipitation. The variation of soil moisture is partly caused by its relation to precipitation, because the $\mathrm{R}$ value between soil moisture and precipitation was found to vary over MJO phases, and the soil moisture is also related to other climate variables such as temperature and evaporation. Overall, the results mentioned above clearly show that the MJO has impacts on the extreme dry and wet conditions of the globe particularly over areas with strong MJO signals. The variation of this dryness/wetness across the MJO phases are directly related to precipitation, soil moisture and air temperature. The results suggest that the MJO impacts should be taken into account in the investigation of dryness/wetness around the world particularly over monsoon areas. It should also be noted that there are uncertainties associated with satellite-based products such as GPCP precipitation, ESA CCI soil moisture and GLEAM ET/PET datasets. For studies that aiming to quantify the impacts of MJO on dry and wet conditions over regional scale, the uncertainties of satellite-based products should be taken into account. 
Table 1. Averaged correlation between dryness/wetness and precipitation, soil moisture, and air temperature across MJO phases for Globe and selected regions.

\begin{tabular}{lllllll}
\hline & & Globe & South Asia & South America & East Africa & Australia \\
\hline \multirow{2}{*}{ Precipitation } & R (Summer) & 0.376 & 0.733 & 0.557 & 0.791 & 0.608 \\
& R (Winter) & 0.279 & 0.547 & 0.454 & 0.776 & 0.677 \\
& R (Summer) & 0.473 & 0.791 & 0.699 & 0.788 & 0.78 \\
Soil moisture & R (Winter) & 0.466 & 0.711 & 0.725 & 0.808 & 0.719 \\
& R (Summer) & -0.415 & -0.622 & -0.502 & -0.61 & -0.257 \\
& R (Winter) & -0.246 & -0.088 & -0.508 & -0.576 & -0.6 \\
\hline
\end{tabular}

\section{Conclusions}

To the best of our knowledge, this study is the first to reveal the impacts of MJO on the global extreme dry and wet conditions based on observations. All previous works have focused on either extreme precipitation or droughts over specific geographic locations. Given the planetary scale of the MJO, the current study first developed an observational analysis to obtain a global view of the relation between the MJO and global dryness and wetness that were represented by ESI drought index. It is found that MJO has nearly global influences on the extreme dry and wet conditions particularly over monsoon regions (e.g. South Asia, South America and East Africa) via the effects of MJO on precipitation, soil moisture and air temperature, which are induced by modifying the meridional overturning circulations, and exciting Rossby wave trains caused by heating anomalies, and moisture transport, and forcing zonally-propagating equatorial Rossby and Kelvin waves. The results suggest that the impacts of MJO should be accounted for in studies of droughts and floods in areas where MJO has strong 
impacts such as South Asia. In addition, the findings of the present study provide the basis for drought analysis and MJO-based monitoring and prediction systems, which would support decision-making in climate sensitive sectors such as drought monitoring and agricultural management. However, it should be noted that the current study only provides an observational analysis of the impacts of MJO on global extreme dry and wet conditions. The applied satellitebased products such as GLEAM ET/PET, ESA CCI soil moisture still have uncertainties, which should be accounted for in future studies to quantify their impacts on related dryness and wetness.

\section{Acknowledgments}

We thank the GLEAM team, European Space Agency (ESA), European Centre for MediumRange Weather Forecasts (ECMWF) and Integrated Climate Data Centre (ICDC) for providing the datasets used in this study. The present study was supported by UK space Agency's International Partnership Programme (417000001429), Multiply EU-Horizon 2020 project (687320) as well as China NSFC Project, Grant No. 41775075.

\section{References}

Anderson, M.C., Norman, J.M., Mecikalski, J.R., Otkin, J.A., \& Kustas, W.P. (2007). A climatological study of evapotranspiration and moisture stress across the continental United States based on thermal remote sensing: 2. Surface moisture climatology. Journal of Geophysical Research: Atmospheres, 112, n/a-n/a

Anderson, M.C., Zolin, C.A., Hain, C.R., Semmens, K., Yilmaz, M.T., \& Gao, F. (2015). Comparison of satellitederived LAI and precipitation anomalies over Brazil with a thermal infrared-based Evaporative Stress Index for 2003-2013. Journal of Hydrology, 526, 287-302

Anderson, M.C., Zolin, C.A., Sentelhas, P.C., Hain, C.R., Semmens, K., Tugrul Yilmaz, M., Gao, F., Otkin, J.A., \& Tetrault, R. (2016). The Evaporative Stress Index as an indicator of agricultural drought in Brazil: An assessment based on crop yield impacts. Remote Sensing of Environment, 174, 82-99

Barlow, M., Nigam, S., \& Berbery, E.H. (2001). ENSO, Pacific decadal variability, and US summertime precipitation, drought, and stream flow. Journal of Climate, 14, 2105-2128

Betts, A.K., Köhler, M., \& Zhang, Y. (2009). Comparison of river basin hydrometeorology in ERA-Interim and ERA-40 reanalyses with observations. Journal of Geophysical Research: Atmospheres, 114

Cayan, D.R., Dettinger, M.D., Diaz, H.F., \& Graham, N.E. (1998). Decadal variability of precipitation over western North America. Journal of Climate, 11, 3148-3166 
Choi, M., Jacobs, J.M., Anderson, M.C., \& Bosch, D.D. (2013). Evaluation of drought indices via remotely sensed data with hydrological variables. Journal of Hydrology, 476, 265-273

Crueger, T., Stevens, B., \& Brokopf, R. (2013). The Madden-Julian Oscillation in ECHAM6 and the Introduction of an Objective MJO Metric. Journal of Climate, 26, 3241-3257

Dai, A. (2013). Increasing drought under global warming in observations and models. Nature Climate Change, 3, 52

Dee, D.P., Uppala, S.M., Simmons, A.J., Berrisford, P., Poli, P., Kobayashi, S., Andrae, U., Balmaseda, M.A., Balsamo, G., Bauer, P., Bechtold, P., Beljaars, A.C.M., van de Berg, L., Bidlot, J., Bormann, N., Delsol, C., Dragani, R., Fuentes, M., Geer, A.J., Haimberger, L., Healy, S.B., Hersbach, H., Hólm, E.V., Isaksen, L., Kållberg, P., Köhler, M., Matricardi, M., McNally, A.P., Monge-Sanz, B.M., Morcrette, J.J., Park, B.K., Peubey, C., de Rosnay, P., Tavolato, C., Thépaut, J.N., \& Vitart, F. (2011). The ERA-Interim reanalysis: configuration and performance of the data assimilation system. Quarterly Journal of the Royal Meteorological Society, 137, 553-597

Dettinger, M. (2011). Climate change, atmospheric rivers, and floods in California-a multimodel analysis of storm frequency and magnitude changes 1. JAWRA Journal of the American Water Resources Association, 47, 514-523

Donald, A., Meinke, H., Power, B., Maia, A.d.H., Wheeler, M.C., White, N., Stone, R.C., \& Ribbe, J. (2006). Near-global impact of the Madden-Julian Oscillation on rainfall. Geophysical Research Letters, 33

Dorigo, W., Gruber, A., De Jeu, R., Wagner, W., Stacke, T., Loew, A., Albergel, C., Brocca, L., Chung, D., \& Parinussa, R. (2015a). Evaluation of the ESA CCI soil moisture product using ground-based observations. Remote Sensing of Environment, 162, 380-395

Dorigo, W.A., Gruber, A., De Jeu, R.A.M., Wagner, W., Stacke, T., Loew, A., Albergel, C., Brocca, L., Chung, D., Parinussa, R.M., \& Kidd, R. (2015b). Evaluation of the ESA CCI soil moisture product using ground-based observations. Remote Sensing of Environment, 162, 380-395

Easterling, D.R., Meehl, G.A., Parmesan, C., Changnon, S.A., Karl, T.R., \& Mearns, L.O. (2000). Climate extremes: observations, modeling, and impacts. Science, 289, 2068-2074

Forzieri, G., Alkama, R., Miralles, D.G., \& Cescatti, A. (2017). Satellites reveal contrasting responses of regional climate to the widespread greening of Earth. Science, 356, 1180-1184

Frank, W.M., \& Roundy, P.E. (2006). The Role of Tropical Waves in Tropical Cyclogenesis. Monthly Weather Review, 134, 2397-2417

Frei, C., Schöll, R., Fukutome, S., Schmidli, J., \& Vidale, P.L. (2006). Future change of precipitation extremes in Europe: Intercomparison of scenarios from regional climate models. Journal of Geophysical Research: Atmospheres, 111

Greve, P., Orlowsky, B., Mueller, B., Sheffield, J., Reichstein, M., \& Seneviratne, S.I. (2014). Global assessment of trends in wetting and drying over land. Nature geoscience, 7, 716

Han, W. (2005). Origins and Dynamics of the 90-Day and 30-60-Day Variations in the Equatorial Indian Ocean. Journal of Physical Oceanography, 35, 708-728

He, J., Lin, H., \& Wu, Z. (2011). Another look at influences of the Madden-Julian Oscillation on the wintertime East Asian weather. Journal of Geophysical Research: Atmospheres, 116

Hu, Y., Li, D., \& Liu, J. (2007). Abrupt seasonal variation of the ITCZ and the Hadley circulation. Geophysical Research Letters, 34 
Huffman, G.J., Adler, R.F., Morrissey, M.M., Bolvin, D.T., Curtis, S., Joyce, R., McGavock, B., \& Susskind, J. (2001). Global Precipitation at One-Degree Daily Resolution from Multisatellite Observations. Journal of Hydrometeorology, 2, 36-50

Inness, P.M., \& Slingo, J.M. (2003). Simulation of the Madden-Julian oscillation in a coupled general circulation model. Part I: Comparison with observations and an atmosphere-only GCM. Journal of Climate, 16, 345-364

IPCC (2013). Climate change 2013: the physical science basis: Working Group I contribution to the Fifth assessment report of the Intergovernmental Panel on Climate Change. Cambridge University Press

Janicot, S., Mounier, F., Hall, N.M., Leroux, S., Sultan, B., \& Kiladis, G.N. (2009). Dynamics of the West African monsoon. Part IV: Analysis of 25-90-day variability of convection and the role of the Indian monsoon. Journal of Climate, 22, 1541-1565

Jia, X., Chen, L., Ren, F., \& Li, C. (2011). Impacts of the MJO on winter rainfall and circulation in China. Advances in Atmospheric Sciences, 28, 521-533

Jones, C., Waliser, D.E., Lau, K., \& Stern, W. (2004a). Global occurrences of extreme precipitation and the Madden-Julian Oscillation: Observations and predictability. Journal of Climate, 17, 4575-4589

Jones, C., Waliser, D.E., Lau, K., \& Stern, W. (2004b). Global occurrences of extreme precipitation and the Madden-Julian oscillation: Observations and predictability. Journal of Climate, 17, 4575-4589

Joseph, S., Sahai, A.K., \& Goswami, B.N. (2009). Eastward propagating MJO during boreal summer and Indian monsoon droughts. Climate Dynamics, 32, 1139-1153

Kang, I.-S., \& Kim, H.-M. (2010). Assessment of MJO Predictability for Boreal Winter with Various Statistical and Dynamical Models. Journal of Climate, 23, 2368-2378

Kenyon, J., \& Hegerl, G.C. (2010). Influence of modes of climate variability on global precipitation extremes. Journal of Climate, 23, 6248-6262

Kim, D., Kim, H., \& Lee, M.-I. (2017). Why does the MJO detour the Maritime Continent during austral summer? Geophysical Research Letters, 44, 2579-2587

Knutti, R., \& Sedláček, J. (2013). Robustness and uncertainties in the new CMIP5 climate model projections. Nature Climate Change, 3, 369

Leng, P., Li, Z.L., Duan, S.B., Tang, R., \& Gao, M.F. (2017). A method for deriving all-sky evapotranspiration from the synergistic use of remotely sensed images and meteorological data. Journal of Geophysical Research: Atmospheres

Li, W., Guo, W., Hsu, P.-c., \& Xue, Y. (2016). Influence of the Madden-Julian oscillation on Tibetan Plateau snow cover at the intraseasonal time-scale. Scientific Reports, 6, 30456

Lian, X., Piao, S., Huntingford, C., Li, Y., Zeng, Z., Wang, X., Ciais, P., McVicar, T.R., Peng, S., Ottlé, C., Yang, H., Yang, Y., Zhang, Y., \& Wang, T. (2018). Partitioning global land evapotranspiration using CMIP5 models constrained by observations. Nature Climate Change, 8, 640-646

Liu, M., Xu, X., Xu, C., Sun, A.Y., Wang, K., Scanlon, B.R., \& Zhang, L. (2017a). A new drought index that considers the joint effects of climate and land surface change. Water Resources Research, 53, 3262-3278 
Liu, X., Wu, T., Yang, S., Li, T., Jie, W., Zhang, L., Wang, Z., Liang, X., Li, Q., Cheng, Y., Ren, H., Fang, Y., \& Nie, S. (2017b). MJO prediction using the sub-seasonal to seasonal forecast model of Beijing Climate Center. Climate Dynamics, 48, 3283-3307

Liu, Y.Y., Parinussa, R.M., Dorigo, W.A., De Jeu, R.A.M., Wagner, W., van Dijk, A.I.J.M., McCabe, M.F., \& Evans, J.P. (2011). Developing an improved soil moisture dataset by blending passive and active microwave satellite-based retrievals. Hydrology and Earth System Sciences, 15, 425-436

Lü, J., Ju, J., Ren, J., \& Gan, W. (2012). The influence of the Madden-Julian Oscillation activity anomalies on Yunnan's extreme drought of 2009-2010. Science China Earth Sciences, 55, 98-112

Madden, R.A., \& Julian, P.R. (1971). Detection of a 40-50 Day Oscillation in the Zonal Wind in the Tropical Pacific. Journal of the Atmospheric Sciences, 28, 702-708

Martens, B., Miralles, D.G., Lievens, H., van der Schalie, R., de Jeu, R.A.M., Fernández-Prieto, D., Beck, H.E., Dorigo, W.A., \& Verhoest, N.E.C. (2017). GLEAM v3: satellite-based land evaporation and root-zone soil moisture. Geosci. Model Dev., 10, 1903-1925

Matsueda, S., \& Takaya, Y. (2015). The global influence of the Madden-Julian oscillation on extreme temperature events. Journal of Climate, 28, 4141-4151

Matthews, A.J., Hoskins, B.J., \& Masutani, M. (2004). The global response to tropical heating in the Madden-Julian oscillation during the northern winter. Quarterly Journal of the Royal Meteorological Society, 130, 1991-2011

Meehl, G.A., Zwiers, F., Evans, J., Knutson, T., Mearns, L., \& Whetton, P. (2000). Trends in extreme weather and climate events: issues related to modeling extremes in projections of future climate change. Bulletin of the American Meteorological Society, 81, 427-436

Miralles, D.G., Holmes, T.R.H., De Jeu, R.A.M., Gash, J.H., Meesters, A.G.C.A., \& Dolman, A.J. (2011). Global land-surface evaporation estimated from satellite-based observations. Hydrol. Earth Syst. Sci., 15, 453-469

Miralles, D.G., Van Den Berg, M.J., Gash, J.H., Parinussa, R.M., De Jeu, R.A., Beck, H.E., Holmes, T.R., Jiménez, C., Verhoest, N.E., \& Dorigo, W.A. (2014). El Niño-La Niña cycle and recent trends in continental evaporation. Nature Climate Change, 4, 122

Neena, J.M., Suhas, E., \& Goswami, B.N. (2011). Leading role of internal dynamics in the 2009 Indian summer monsoon drought. Journal of Geophysical Research: Atmospheres, 116

Nicolai-Shaw, N., Zscheischler, J., Hirschi, M., Gudmundsson, L., \& Seneviratne, S.I. (2017). A drought event composite analysis using satellite remote-sensing based soil moisture. Remote Sensing of Environment, 203, 216225

Otkin, J.A., Anderson, M.C., Hain, C., \& Svoboda, M. (2013). Examining the Relationship between Drought Development and Rapid Changes in the Evaporative Stress Index. Journal of Hydrometeorology, 15, 938-956

Otkin, J.A., Anderson, M.C., Hain, C., \& Svoboda, M. (2014). Examining the relationship between drought development and rapid changes in the evaporative stress index. Journal of Hydrometeorology, 15, 938-956

Pai, D.S., Bhate, J., Sreejith, O.P., \& Hatwar, H.R. (2011). Impact of MJO on the intraseasonal variation of summer monsoon rainfall over India. Climate Dynamics, 36, 41-55

Peng, J., \& Loew, A. (2017). Recent Advances in Soil Moisture Estimation from Remote Sensing. Water, 9, 530 
Peng, J., Loew, A., \& Crueger, T. (2017a). The relationship between the Madden-Julian oscillation and the land surface soil moisture. Remote Sensing of Environment, 203, 226-239

Peng, J., Loew, A., Merlin, O., \& Verhoest, N.E. (2017d). A review of spatial downscaling of satellite remotely sensed soil moisture. Reviews of Geophysics, 55, 341-366

Peng, J., Loew, A., Zhang, S., Wang, J., \& Niesel, J. (2016). Spatial Downscaling of Satellite Soil Moisture Data Using a Vegetation Temperature Condition Index. IEEE Transactions on Geoscience and Remote Sensing, 54, 558566

Peng, J., Niesel, J., Loew, A., Zhang, S., \& Wang, J. (2015). Evaluation of Satellite and Reanalysis Soil Moisture Products over Southwest China Using Ground-Based Measurements. Remote Sensing, 7, 15729

Pohl, B., \& Camberlin, P. (2006). Influence of the Madden-Julian oscillation on East African rainfall. I: Intraseasonal variability and regional dependency. Quarterly Journal of the Royal Meteorological Society, 132, 2521-2539

Pohl, B., \& Matthews, A.J. (2007). Observed Changes in the Lifetime and Amplitude of the Madden-Julian Oscillation Associated with Interannual ENSO Sea Surface Temperature Anomalies. Journal of Climate, 20, 26592674

Priestley, C.H.B., \& Taylor, R.J. (1972). On the Assessment of Surface Heat Flux and Evaporation Using LargeScale Parameters. Monthly Weather Review, 100, 81-92

Reid, J.S., Xian, P., Hyer, E.J., Flatau, M.K., Ramirez, E.M., Turk, F.J., Sampson, C.R., Zhang, C., Fukada, E.M., \& Maloney, E.D. (2012). Multi-scale meteorological conceptual analysis of observed active fire hotspot activity and smoke optical depth in the Maritime Continent. Atmos. Chem. Phys., 12, 2117-2147

Richard, W., Sonia, I.S., Martin, H., Jinfeng, C., Philippe, C., Delphine, D., Joshua, E., Christian, F., Simon, N.G., Lukas, G., Alexandra-Jane, H., Thomas, H., Akihiko, I., Nikolay, K., Hyungjun, K., Guoyong, L., Junguo, L., Xingcai, L., Yoshimitsu, M., Catherine, M., Christoph, M., Hannes Müller, S., Kazuya, N., Rene, O., Yadu, P., Thomas, A.M.P., Yusuke, S., Sibyll, S., Erwin, S., Justin, S., Tobias, S., Joerg, S., Qiuhong, T., Wim, T., Yoshihide, W., Xuhui, W., Graham, P.W., Hong, Y., \& Tian, Z. (2018). Evapotranspiration simulations in ISIMIP2aEvaluation of spatio-temporal characteristics with a comprehensive ensemble of independent datasets. Environmental Research Letters, 13, 075001

Robertson, A.W., Camargo, S.J., Sobel, A., Vitart, F., \& Wang, S. (2018). Summary of workshop on sub-seasonal to seasonal predictability of extreme weather and climate. npj Climate and Atmospheric Science, 1, 20178

Seager, R., Ting, M., Li, C., Naik, N., Cook, B., Nakamura, J., \& Liu, H. (2013). Projections of declining surfacewater availability for the southwestern United States. Nature Clim. Change, 3, 482-486

Sheffield, J., Andreadis, K.M., Wood, E.F., \& Lettenmaier, D.P. (2009). Global and Continental Drought in the Second Half of the Twentieth Century: Severity-Area-Duration Analysis and Temporal Variability of Large-Scale Events. Journal of Climate, 22, 1962-1981

Shimizu, M.H., Ambrizzi, T., \& Liebmann, B. (2017). Extreme precipitation events and their relationship with ENSO and MJO phases over northern South America. International Journal of Climatology, 37, 2977-2989

Sillmann, J., Kharin, V., Zwiers, F., Zhang, X., \& Bronaugh, D. (2013). Climate extremes indices in the CMIP5 multimodel ensemble: Part 2. Future climate projections. Journal of Geophysical Research: Atmospheres, 118, $2473-2493$ 
Sillmann, J., Thorarinsdottir, T., Keenlyside, N., Schaller, N., Alexander, L.V., Hegerl, G., Seneviratne, S.I., Vautard, R., Zhang, X., \& Zwiers, F.W. (2017). Understanding, modeling and predicting weather and climate extremes: Challenges and opportunities. Weather and Climate Extremes, 18, 65-74

Sun, Q., Miao, C., AghaKouchak, A., \& Duan, Q. (2016a). Century-scale causal relationships between global dry/wet conditions and the state of the Pacific and Atlantic Oceans. Geophysical Research Letters, 43, 6528-6537

Sun, S., Chen, H., Ju, W., Yu, M., Hua, W., \& Yin, Y. (2014). On the attribution of the changing hydrological cycle in Poyang Lake Basin, China. Journal of Hydrology, 514, 214-225

Sun, S., Chen, H., Wang, G., Li, J., Mu, M., Yan, G., Xu, B., Huang, J., Wang, J., \& Zhang, F. (2016c). Shift in potential evapotranspiration and its implications for dryness/wetness over Southwest China. Journal of Geophysical Research: Atmospheres, 121, 9342-9355

Sylla, M., Giorgi, F., Coppola, E., \& Mariotti, L. (2013). Uncertainties in daily rainfall over Africa: assessment of gridded observation products and evaluation of a regional climate model simulation. International Journal of Climatology, 33, 1805-1817

Szczypta, C., Calvet, J.C., Albergel, C., Balsamo, G., Boussetta, S., Carrer, D., Lafont, S., \& Meurey, C. (2011). Verification of the new ECMWF ERA-Interim reanalysis over France. Hydrology and Earth System Sciences, 15, 647-666

Tan, M.L., Ibrahim, A.L., Cracknell, A.P., \& Yusop, Z. (2017). Changes in precipitation extremes over the Kelantan River Basin, Malaysia. International Journal of Climatology, 37, 3780-3797

Thompson, D.B., \& Roundy, P.E. (2013). The Relationship between the Madden-Julian Oscillation and U.S. Violent Tornado Outbreaks in the Spring. Monthly Weather Review, 141, 2087-2095

Trenberth, K.E., Cheng, L., Jacobs, P., Zhang, Y., \& Fasullo, J. (2018). Hurricane Harvey Links to Ocean Heat Content and Climate Change Adaptation. Earth's Future, 6, 730-744

Trenberth, K.E., \& Shea, D.J. (2005). Relationships between precipitation and surface temperature. Geophysical Research Letters, 32

Vecchi, G.A., \& Bond, N.A. (2004). The Madden-Julian Oscillation (MJO) and northern high latitude wintertime surface air temperatures. Geophysical Research Letters, 31

Vicente-Serrano, S.M., Miralles, D.G., Domínguez-Castro, F., Azorin-Molina, C., Kenawy, A.E., McVicar, T.R., Tomás-Burguera, M., Beguería, S., Maneta, M., \& Peña-Gallardo, M. (2018). Global Assessment of the Standardized Evapotranspiration Deficit Index (SEDI) for Drought Analysis and Monitoring. Journal of Climate, $31,5371-5393$

Waliser, D., Lau, K., Stern, W., \& Jones, C. (2003). Potential predictability of the Madden-Julian oscillation. Bulletin of the American Meteorological Society, 84, 33-50

Waliser, D., Sperber, K., Hendon, H., Kim, D., Maloney, E., Wheeler, M., Weickmann, K., Zhang, C., Donner, L., Gottschalck, J., Higgins, W., Kang, I.-S., Legler, D., Moncrieff, M., Schubert, S., Stern, W., VItart, F., Wang, B., Wang, W., \& Woolnough, S. (2009). MJO Simulation Diagnostics. Journal of Climate, 22, 3006-3030

Weisheimer, A., Schaller, N., O'Reilly, C., MacLeod, D.A., \& Palmer, T. (2017). Atmospheric seasonal forecasts of the twentieth century: multi-decadal variability in predictive skill of the winter North Atlantic Oscillation (NAO) and their potential value for extreme event attribution. Quarterly Journal of the Royal Meteorological Society, 143, 917-926 
Wheeler, M.C., \& Hendon, H.H. (2004). An All-Season Real-Time Multivariate MJO Index: Development of an Index for Monitoring and Prediction. Monthly Weather Review, 132, 1917-1932

Xavier, P., Rahmat, R., Cheong, W.K., \& Wallace, E. (2014). Influence of Madden-Julian Oscillation on Southeast Asia rainfall extremes: Observations and predictability. Geophysical Research Letters, 41, 4406-4412

Yuan, X., Ma, Z., Pan, M., \& Shi, C. (2015). Microwave remote sensing of short-term droughts during crop growing seasons. Geophysical Research Letters, 42, 4394-4401

Zhang, B., AghaKouchak, A., Yang, Y., Wei, J., \& Wang, G. (2019). A water-energy balance approach for multicategory drought assessment across globally diverse hydrological basins. Agricultural and forest meteorology, 264, 247-265

Zhang, B., \& He, C. (2016). A modified water demand estimation method for drought identification over arid and semiarid regions. Agricultural and forest meteorology, 230-231, 58-66

Zhang, B., Zhao, X., Jin, J., \& Wu, P. (2015). Development and evaluation of a physically based multiscalar drought index: The Standardized Moisture Anomaly Index. Journal of Geophysical Research: Atmospheres, 120, 11,575511,588

Zhang, C. (2005). Madden-Julian Oscillation. Reviews of Geophysics, 43

Zhang, C. (2013). Madden-Julian Oscillation: Bridging Weather and Climate. Bulletin of the American Meteorological Society, 94, 1849-1870

Zhang, C., \& Dong, M. (2004). Seasonality in the Madden-Julian Oscillation. Journal of Climate, 17, 3169-3180

Zhang, X., Wang, J., Zwiers, F.W., \& Groisman, P.Y. (2010). The influence of large-scale climate variability on winter maximum daily precipitation over North America. Journal of Climate, 23, 2902-2915

Zheng, C., Kar-Man Chang, E., Kim, H.-M., Zhang, M., \& Wang, W. (2018). Impacts of the Madden-Julian Oscillation on Storm-Track Activity, Surface Air Temperature, and Precipitation over North America. Journal of Climate, 31, 6113-6134

Zhou, S., L'Heureux, M., Weaver, S., \& Kumar, A. (2012). A composite study of the MJO influence on the surface air temperature and precipitation over the continental United States. Climate Dynamics, 38, 1459-1471

Zhou, Y., Lu, Y., Yang, B., Jiang, J., Huang, A., Zhao, Y., La, M., \& Yang, Q. (2016). On the relationship between the Madden-Julian Oscillation and $2 \mathrm{~m}$ air temperature over central Asia in boreal winter. Journal of Geophysical Research: Atmospheres, 121, 13,250-213,272 